Selected Papers from the 23rd International Radiocarbon Conference, Trondheim, Norway, 17-22 June, 2018 (C) 2019 by the Arizona Board of Regents on behalf of the University of Arizona. This is an Open Access article, distributed under the terms of the Creative Commons Attribution-NonCommercial-ShareAlike licence (http://creativecommons.org/licenses/by-nc-sa/4.0/), which permits non-commercial re-use, distribution, and reproduction in any medium, provided the same Creative Commons licence is included and the original work is properly cited. The written permission of Cambridge University Press must be obtained for commercial re-use.

\title{
RADIOCARBON AGE OFFSETS OF PLANTS AND SHELLS IN HOLOCENE SEDIMENTS FROM THE SUKUMO PLAIN, SOUTHWEST COAST OF SHIKOKU, SOUTHWEST JAPAN
}

\author{
Toshimichi Nakanishi ${ }^{1,2 *}$ - Tomohiro Tsuji ${ }^{3} \cdot$ Futoshi Nanayama $^{4,5}$ • \\ Tatsuhiko Yamaguchi ${ }^{6} \cdot$ Yasuo Kondo $^{7} \cdot$ Michiharu Ikeda $^{8} \cdot$ Wan Hong $^{9}$ (i) \\ ${ }^{1}$ Institute for Geothermal Sciences, Graduate School of Science, Kyoto University, Noguchibaru, Beppu, Oita \\ 874-0903, Japan \\ ${ }^{2}$ Present address: Tono Geoscience Center, Japan Atomic Energy Agency, 959-31, Jorinji, Izumi-cho, Toki, Gifu \\ 509-5102, Japan \\ ${ }^{3}$ Graduate School of Sciences and Technology for Innovation, Yamaguchi University, 1677-1 Yoshida, Yamaguchi \\ 753-8511, Japan \\ ${ }^{4}$ Geological Survey of Japan, Advanced Industrial Science \& Technology, Higashi 1-1-1, Tsukuba, Ibaraki 305-8567, \\ Japan \\ ${ }^{5}$ Implementation Research and Education System Center for Reducing Disaster Risk, Graduate School of Science and \\ Technology, Kumamoto University, 2-39-1, Chuo-ku, Kurokami, Kumamoto 860-8555, Japan \\ ${ }^{6}$ National Museum of Nature and Science, 4-1-1 Amakubo, Tsukuba, Ibaraki 305-0005, Japan \\ ${ }^{7}$ Research \& Education Faculty, Kochi University, 2-5-1 Akebono-cho, Kochi 780-8520, Japan \\ ${ }^{8}$ Civil Engineering Geology Group, Shikoku Research Institute Inc., 2109-8, Yashima-nishi-machi, Takamatsu, \\ Kagawa 761-0113, Japan \\ ${ }^{9}$ Geochemical Analysis Center, Korea Institute of Geoscience \& Mineral Resources, 124 Gwahak-ro, Yuseong-gu, \\ Daejeon 34132, Republic of Korea
}

\begin{abstract}
To identify chronological changes in the marine reservoir effect in southwest Japan, the radiocarbon ages of eight pairs of marine shells and terrestrial plants were measured from the same horizons of one core of Holocene sediments. This core was obtained from the northern part of the Sukumo Plain in southwestern Shikoku Island, which faces the warm Kuroshio Current. The drilling site is located in an area of subsidence associated with the convergence of the Philippine Sea Plate and the Eurasian Plate. On analyses of lithology, molluscan assemblages, and radiocarbon dating, we interpreted, from oldest to youngest, nine units: basement rock, a braided river channel, a meandering river channel, an estuary, a transgressive inner bay, Kikai-Akahoya volcanic ash, a deltaic inner bay, a tidal flat, and artificial soil. Changes in the depositional environment were mainly associated with sea-level rise after the end of the last glaciation. The reservoir ages of the eight pairs, $330 \pm 70 \mathrm{yr}$, were obtained from a transgressive inner bay to deltaic inner bay sediments, formed during 4100-9200 cal BP. The chronological change in the reservoir effect allows us to correlate the Sukumo Core sediments with previous results from southwestern Japan, the Korean Peninsula, and Taiwan Island.
\end{abstract}

KEYWORDS: Holocene, Kuroshio Current, marine reservoir, radiocarbon dating, sedimentary facies.

\section{INTRODUCTION}

Radiocarbon $\left({ }^{14} \mathrm{C}\right)$ marine reservoir effects (MRE) have been determined from Holocene coastal sediments in the East Asia region (Yu et al. 2010; Nakanishi et al. 2013, 2015, 2017a, 2017b, 2017c; Nakamura et al. 2016; Yang et al. 2018). The reservoir ages ranged from 60 to $1100 \mathrm{yr}$, scattered over the period 100-10,200 cal BP, which were significantly larger than the values from "prebomb" samples of known age, before AD 1955 in this area (Figure 1A; Konishi et al. 1982; Hideshima et al. 2001; Kuzmin et al. 2001, 2007; Southon et al. 2002; Kong and Lee 2005; Shishikura et al. 2007; Yoneda et al. 2007; Hirabayashi et al. 2017).

*Corresponding author. Email: mid24t@gmail.com. 


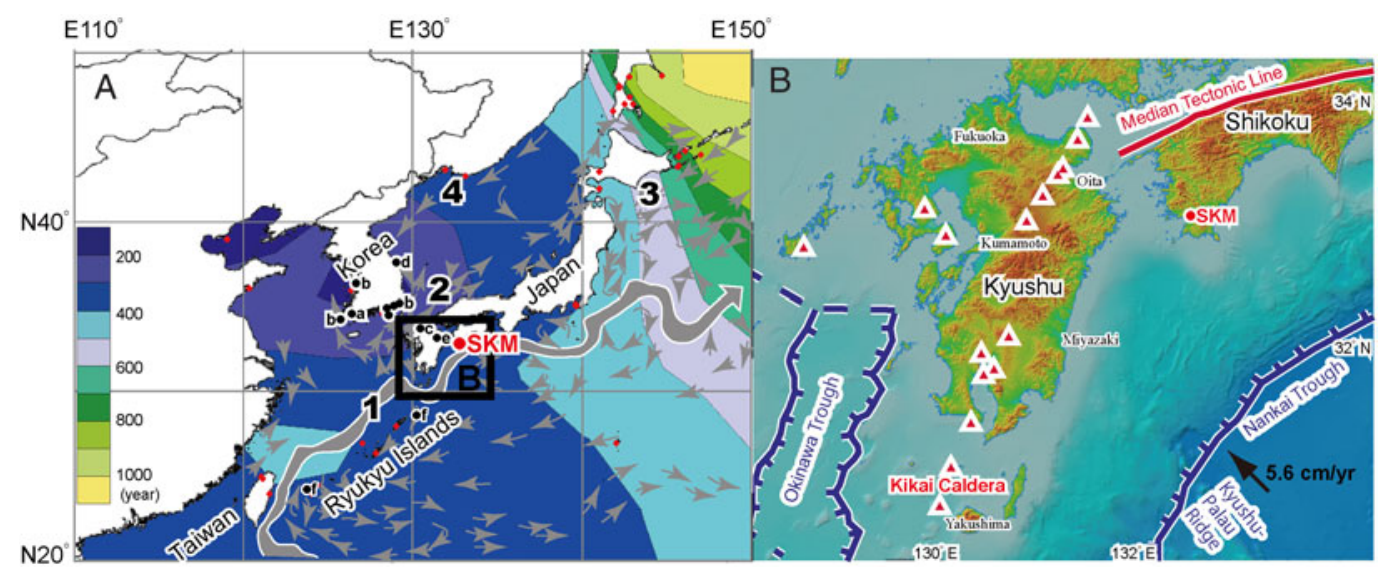

Figure 1 A: Study sites and modern marine reservoir ages in East Asia (modified after Nakanishi et al. 2015). Data from The Marine Reservoir Database. 1, Kuroshio Current; 2, Tsushima Current; 3, Oyashio Current; 4, Liman Current; a, YAR-4 from Nakanishi et al. (2013); b, study sites from Nakanishi et al. (2015); c, HKA and HIUB from Nakanishi et al. (2017a); d, PMR-2 from Nakanishi et al. (2017b); e, KUO-1 from Nakanishi et al. (2017c). f, study sites from Hirabayashi et al. (2017). B: Tectonic map around the Kyushu area and drilling site of Sukumo (SKM) core. The base map is modeled after the Geospatial Information Authorityof Japan. Kikai Caldera is the source of the Kikai-Akahoya tephra (Machida and Arai 2003).

These results indicate that the information on MRE is indispensable for chronological control not only from prebomb samples but also from geological and archaeological samples. One such effect from the warm Kuroshio Current environment in southwestern Japan was determined at the Oita Plain within Seto Inland Sea (Nakanishi et al. 2017c). To identify the direct chronological changes of the MRE under the Kuroshio Current, ${ }^{14} \mathrm{C}$ ages from pairs of marine mollusks and terrestrial plants were measured from the same stratigraphic horizons within a single core of Holocene sediments beneath the Sukumo Plain, in the southwestern portion of Shikoku Island. Subsequently, the results were compared with values from the Oita Plain, $310 \pm 130 \mathrm{yr}(\mathrm{n}=7)$, and Hakata Bay, $310 \pm 150 \mathrm{yr}(\mathrm{n}=33)$, on the northern coast of Kyushu (Nakanishi et al. 2017a, 2017c), as well as the Korean Peninsula (Nakanishi et al. 2013, 2015; $380 \pm 190 \mathrm{yr}[\mathrm{n}=48], 2017 \mathrm{~b} ; 450 \pm 230 \mathrm{yr}[\mathrm{n}=9]$ ), the South China Sea (Yu et al. 2010), and Taiwan (Yang et al. 2018).

\section{STUDY SITE}

The Sukumo Plain is situated in the southwestern portion of Shikoku Island, the smallest of the four major islands of Japan (Figure 1A). The plain is located on the subsidence area created by the convergence of the Philippine Sea Plate with the Eurasian Plate (Fitch and Scholz 1971; Okamura 1990). The coastal water around the Sukumo Plain is influenced by the warm Kuroshio Current, which originates from the North Equatorial Current. This alluvial plain is formed by the Matsuda River. A melange matrix of Late Cretaceous to Oligocene accretionary complexes and middle to late Miocene felsic plutonic rocks form the bedrock of this catchment, without any carbonate rocks (Tanaka 1980). The Sukumo (SKM) core was drilled in the northern part of the plain $\left(33^{\circ} 55^{\prime} 55.7^{\prime \prime} \mathrm{N}, 132^{\circ} 42^{\prime} 21.3^{\prime \prime} \mathrm{E}\right.$; elevation $+0.99 \mathrm{~m}$ ) (Tsuji et al. 2018). This drilling site is on reclaimed land and approximately $700 \mathrm{~m}$ north from the mouth of the Matsuda River. The SKM core is $38.5 \mathrm{~m}$ in length and $8 \mathrm{~cm}$ in diameter. It was collected at $1.0 \mathrm{~m}$ intervals, using a double-walled tube sampler. The proportion of core recovery is almost $94 \%$. 


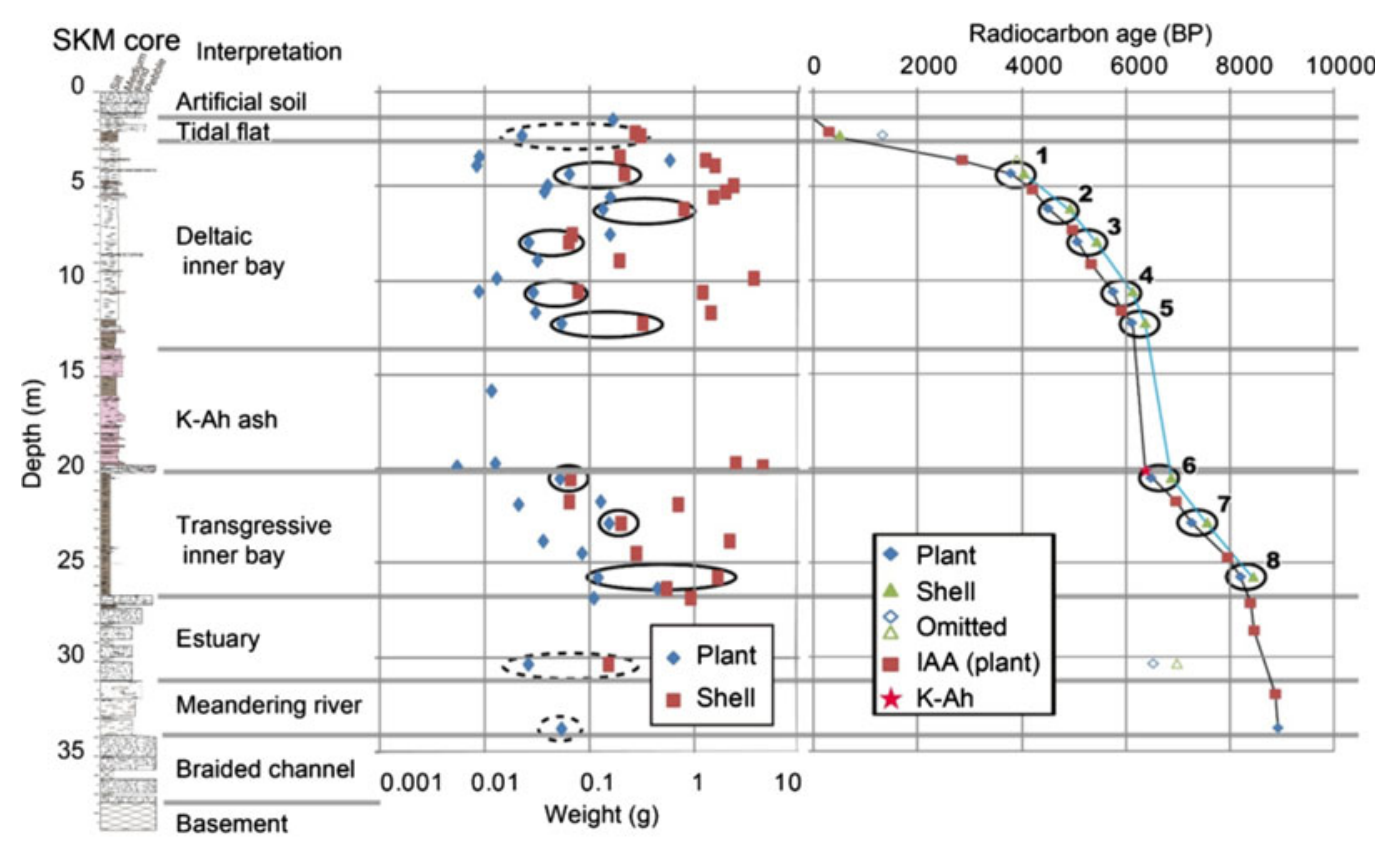

Figure 2 Sediment column of the SKM core with interpretation of paleoenvironments, weights of plant and shell fragments, and ${ }^{14} \mathrm{C}$ ages. Ages of IAA were measured by the Institute of Accelerator Analysis (Tsuji et al. 2018). K-Ah indicates the Kikai-Akahoya tephra.

\section{METHODS}

\section{Sedimentological and Paleontological Analyses}

To infer the sedimentary environments of the SKM core, we described lithologies, colors, sedimentary structures, textures, contract characteristics, fossil components, and grain sizes. In addition, to improve the understanding of sedimentary environments, mollusk assemblages were identified on the basis of the classification of Okutani (2017) and World Register of Marine Species (http://www.marinespecies.org/index.php). Ostracode taxa were identified, using Ishizaki (1968), Yasuhara and Irizuki (2001), and Irizuki et al. (2008) as references.

\section{Accelerator Mass Spectrometry ${ }^{14} \mathrm{C}$ Dating}

Thirty-two terrestrial macrofossils and 30 calcareous marine samples, in good condition, were collected from the core for accelerator mass spectrometry (AMS) ${ }^{14} \mathrm{C}$ dating. The sampling depths and weights are shown in Figure 2. Fragile samples, such as twigs and thin bivalves, as well as articulated shells of dominant species were selected as often as possible because they are less likely to have been reworked. Twelve terrestrial macrofossils and 11 calcareous marine samples were washed repeatedly with an ultrasonic cleaner and then cleaned chemically using acid-base-acid (Brock et al. 2010) for terrestrial plants and an acid treatment for calcareous marine samples to remove secondary contaminants. The sampling depths are listed in Table 1.

The ${ }^{14} \mathrm{C}$ ages from 11 terrestrial plants (Tsuji et al. 2018) by the Institute of Accelerator Analysis Ltd. (IAA) provided an age model of the sedimentation in this site. Samples of 
Table 1 Radiocarbon ages from the SKM core. Errors are $1 \sigma$ ranges. Medium depths with an asterisk $(* 1-8)$ are those used to measure the marine reservoir age. Radiocarbon ages with a cross $\left(^{+}\right)$and circle $\left(^{\circ}\right)$ were interpreted from reworked samples and dropped samples, respectively.

\begin{tabular}{|c|c|c|c|c|c|c|c|c|}
\hline \multicolumn{3}{|c|}{ Depth (m) } & \multirow[b]{2}{*}{ Material } & \multirow{2}{*}{$\begin{array}{l}\delta^{13} \mathrm{C} \\
(\% 0)\end{array}$} & \multirow{2}{*}{$\begin{array}{c}1 \sigma \\
(\%)\end{array}$} & \multirow{2}{*}{$\begin{array}{l}\text { Conventional } \\
\text { age (BP) }\end{array}$} & \multirow{2}{*}{$\begin{array}{l}1 \sigma \\
(\mathrm{yr})\end{array}$} & \multirow{2}{*}{$\frac{\text { Lab code }}{\text { KGM-O }}$} \\
\hline Top & Bottom & Medium & & & & & & \\
\hline \multirow[t]{2}{*}{2.25} & 2.27 & 2.26 & Wood & -27.1 & 1.0 & $1310^{+}$ & 30 & Wd180037 \\
\hline & & & $\begin{array}{l}\text { Ruditapes } \\
\text { philippinarum } \\
\text { (jointed) }\end{array}$ & -1.2 & 2.5 & 490 & 30 & Ca180013 \\
\hline \multirow[t]{2}{*}{3.55} & 3.59 & 3.57 & Twig & -27.7 & 0.9 & 2780 & 30 & Wd180038 \\
\hline & & & Shell fragment & 3.5 & 0.9 & $3890^{+}$ & 40 & Ca180014 \\
\hline \multirow[t]{2}{*}{4.29} & 4.31 & $4.30^{* 1}$ & Plant fragments & -29.4 & 0.3 & 3770 & 40 & Wd180039 \\
\hline & & & Shell fragments & 1.2 & 0.9 & & 40 & Ca180015 \\
\hline \multirow[t]{2}{*}{6.15} & 6.18 & $6.165^{* 2}$ & Twig & -29.0 & 0.7 & 4490 & 40 & Wd 180040 \\
\hline & & & Paratapes undulatus & -0.2 & 3.4 & 4920 & 40 & Ca180016 \\
\hline \multirow[t]{2}{*}{7.92} & 7.94 & $7.93^{* 3}$ & Plant fragments & -29.0 & 0.7 & 5050 & 40 & Wd180041 \\
\hline & & & Paratapes undutatus & 8.8 & 0.9 & 5430 & 40 & Ca180017 \\
\hline \multirow[t]{2}{*}{10.58} & 10.59 & $10.585^{* 4}$ & Plant fragments & -28.3 & 0.5 & 5740 & 40 & Wd1 180042 \\
\hline & & & $\begin{array}{l}\text { Dosinella augulosa } \\
\text { (jointed) }\end{array}$ & 6.8 & 3.2 & 6120 & 40 & Ca180018 \\
\hline \multirow[t]{2}{*}{12.23} & 12.25 & $12.24^{* 5}$ & Plant fragments & -27.3 & 0.4 & 6100 & 40 & Wd180043 \\
\hline & & & Fulvia hungerfordi & 4.1 & 1.6 & 6360 & 40 & Ca180019 \\
\hline \multirow[t]{2}{*}{20.47} & 20.49 & $20.48^{* 6}$ & Plant fragments & -30.3 & 0.3 & 6470 & 40 & Wd180044 \\
\hline & & & Shell fragments & 0.1 & 1.2 & & 40 & Ca180020 \\
\hline \multirow[t]{2}{*}{22.85} & 22.86 & $22.855^{* 7}$ & Wood & -30.7 & 0.4 & 7250 & 40 & Wd180045 \\
\hline & & & Shell fragments & -2.6 & 1.0 & 7550 & 40 & Ca180021 \\
\hline \multirow[t]{2}{*}{25.72} & 25.74 & $25.73^{* 8}$ & Plant fragments & -29.2 & 0.2 & 8190 & 50 & Wd180046 \\
\hline & & & Macoma tokyoensi. & 1.8 & 0.7 & 8440 & 40 & Ca180022 \\
\hline \multirow[t]{2}{*}{30.32} & 30.35 & 30.335 & Plant fragments & -26.9 & 0.5 & $6510^{\circ}$ & 40 & Wd180047 \\
\hline & & & Shell fragments & -1.2 & 4.3 & $6970^{\circ}$ & 40 & Ca180023 \\
\hline 33.70 & 33.80 & 33.75 & Plant fragments & -31.0 & 0.3 & 8910 & 50 & Wd180048 \\
\hline
\end{tabular}

${ }^{14} \mathrm{C}$-free wood and the IAEA C-1 reference material were treated using the same procedure for control measurements. The carbonate samples were powdered using a mortar and pestle. The standards NIST OxII, IAEA C-7, and C-8 were combusted in an elemental analyzer, and the $\mathrm{CO}_{2}$ gas was purified cryogenically in a high-vacuum automatic preparation system (Hong et al. 2010a; Park et al. 2010) and then converted into graphite through the reduction of Fe powder with hydrogen gas in a quartz tube. The ${ }^{14} \mathrm{C}$ ages of the samples were measured along with the standards at a Cockcroft-Walton type $1 \mathrm{MV}$ AMS facility at the Korea Institute of Geosciences and Mineral Resources (KIGAM) (Hong et al. 2010b). The carbon isotopic fractionations were corrected by $\delta^{13} \mathrm{C}$ values, measured at the AMS facility. The ${ }^{14} \mathrm{C}$ reservoir ages and the uncertainty were calculated by the paired samples of terrestrial macrofossils and calcareous marine samples from same horizons. The ${ }^{14} \mathrm{C}$ ages and the uncertainty of the terrestrial samples were converted into calendar dates using IntCal13 (Reimer et al. 2013) and CALIB 7.1 (Stuiver et al. 2018). 


\section{RESULTS}

Seven sedimentary facies were identified on the basis of our core analysis (a braided river channel, a meandering river, an estuary, a transgressive inner bay, Kikai-Akahoya (K-Ah) volcanic ash, a deltaic inner bay, a tidal flat) (Tsuji et al. 2018), as illustrated in Figure 2. The basement was a siltstone of the Oligocene Shimanto Group (Tanaka 1980). These lithofacies are described below, along with remarks, depositional environments, and ages of the facies. The ${ }^{14} \mathrm{C}$ ages are listed in Table 1, and an age/core depth diagram is provided in Figure 2.

\section{Braided River Facies (core depths of 33.90-37.46 m)}

\section{Description}

This sediment facies consisted of alternating beds of sandy gravel layers $(10-40 \mathrm{~cm}$ thick) and gravel-supported silty sand layers $(10-90 \mathrm{~cm}$ thick). The gravel clasts were subangular to subrounded, and the clast diameters were predominantly $5-90 \mathrm{~mm}$. The matrix portion comprised a mixture of silt and medium to coarse sand. No samples for ${ }^{14} \mathrm{C}$ dating were found in this sediment.

\section{Interpretation}

We interpreted this sediment as a braided river channel sediment because such alternating beds of sandy gravel and gravel-supported sand were commonly reported in bedload environments (Miall 1977, 1992).

\section{Meandering River Facies (core depths of 31.00-33.90 m)}

\section{Description}

This sediment consisted of a lower, gravelly sand bed and an upper gravel bed. The matrix portion was mainly composed of cross-laminated medium to coarse sand. Plant remains were found throughout this facies. The ${ }^{14} \mathrm{C}$ age of plant fragments from $33.75 \mathrm{~m}$ depth was $8910 \pm 50 \mathrm{BP}\left(9795-10,203\right.$ cal BP, $2 \sigma$ ranges). No calcareous samples for ${ }^{14} \mathrm{C}$ dating were found in this sediment.

\section{Interpretation}

The terrestrial plant remains and lack of marine mollusks indicated that this facies formed in a freshwater environment. The difference in grain size implies that the flow velocity was stronger toward the upper portion, associated with a migration of the river channel.

\section{Estuary Facies (core depths of $27.25-31.00 \mathrm{~m}$ )}

\section{Description}

This sediment consisted of a lower, gravelly sand bed and upper alternating beds of sandy gravel and mud. The matrix portion mainly consisted of cross-laminated medium- to coarse-grained sand. Plant remains and shell fragments were scattered within this sediment. The ${ }^{14} \mathrm{C}$ ages of plant and shell samples from $30.335 \mathrm{~m}$ depth were $6510 \pm 40 \mathrm{BP}$ (73237492 cal BP, $2 \sigma$ ranges) and $6970 \pm 40 \mathrm{BP}$, respectively.

\section{Interpretation}

The combination of terrestrial plant remains and marine mollusks indicates that this facies formed in an environment with freshwater from a terrestrial source and saline water from a marine source, such as an estuary. The increase in grain size with decreasing depth 
indicates a stronger flow velocity toward the upper portion, associated with a change in sea level and/or transportation of sediments. The absence of rootlets in this sediment implies that it was likely deposited in an area deeper than the intertidal zone.

\section{Transgressive Inner Bay Facies (core depths of 20.07-27.25 m)}

\section{Description}

This facies consisted of fine, soft mud with plants, shells, and a few layers of fine sand. The concentration of plant and shell fragments was higher toward the lower portion. The facies included subtidal molluscan species such as Paratapes undulatus (Born 1778), Rhinoclavis sordidula (Gould 1849), Macoma tokyoensis Makiyama, 1927, and intertidal species such as Pirenella pupiformis Ozawa and Reid, 2016. Bioturbation, e.g., burrows, and concretions were also found throughout this sediment. In the depth interval of $20.28-20.30 \mathrm{~m}$, the ostracod taxa Loxoconcha uranouchiensis, Spinileberis quadriaculeata, Ambtonia obai, and Krithe japonica occurred. The ${ }^{14} \mathrm{C}$ ages of the three pairs of plant and shell samples from 20.48-25.73 $\mathrm{m}$ depth were 6470-8440 BP (7293-9285 cal BP, 2 $\sigma$ ranges).

\section{Interpretation}

The fine mud with its few terrestrial plant remains and intertidal to subtidal molluscan taxa suggests a low-energy condition as deep as the intertidal to subtidal zone. The ostracode taxa dwell in muddy or sandy bottom of an inner bay (e.g. Ishizaki 1968). In particular, $A$. obai and $K$. japonica flourish in the deep basin of an inner bay (e.g., Yasuhara and Irizuki 2001). The decrease of weight in plant and shell detritus with decreasing depth (Figure 2) indicates an upward deepening of water depth associated with a change in sea level and/or transportation of sediments.

\section{K-Ah Volcanic Ash Facies (core depths of 13.56-20.07 m)}

\section{Description}

This facies was characterized by a basal gravel bed at a depth of 19.68-20.07 $\mathrm{m}$ and overlaying sand/mud alternating beds. The basal gravel bed consisted of angular gravels, rock-reef mollusks such as Chama spp. and Crassostrea sp., and coral fragments. The alternating beds of sand and mud had planar lamination with a few burrows and other examples of bioturbation. The facies contained subtidal species of mollusks such as $R$. sordidula and the subtidal and intertidal dwelling Acar plicatum (Dillwyn 1817). A tephra horizon was identified by the high concentration of volcanic glass with bubble walls and small amounts of brown glass at a depth of $19.65 \mathrm{~m}$.

\section{Interpretation}

The volcanic glass was correlated with the widespread K-Ah tephra (Machida and Arai 2003). The age of the K-Ah layer in the terrestrial curve was consistent with the eruption age of 71657303 cal BP (Smith et al. 2013). The gravel bed at the base of K-Ah was identified as an event deposit related to the K-Ah eruption. Angular gravel, shells of rock-reef species, and fragments of coral strongly imply strong currents from outside the inner bay. A similar deposit was also reported in the Oita area (Fujiwara et al. 2010; Nakanishi et al. 2017c), northwest of the drilling site, and Yakushima Island (Geshi et al. 2017; Nanayama and Maeno 2018), southwest of the drilling site (Figure 1B). They suggest that a reexamination of $7.3 \mathrm{ka}$ tsunami event (Maeno et al. 2006; Maeno and Imamura 2007) will be needed, within $300 \mathrm{~km}$ from the caldera. The parallel-laminated sand layers and mud layers with burrows and bioturbation imply a 
rapid accumulation because they contain almost no plant and shell fossils (Figure 2). This is supported by the ${ }^{14} \mathrm{C}$ ages from the lower and upper facies: $2.2 \mathrm{~cm} / \mathrm{yr}$.

\section{Deltaic Inner Bay Facies (core depths of 2.16-13.56 m)}

\section{Description}

This facies consisted of fine-grained soft mud with plants, and shells intercalated with sand and conglomerate layers. Bioturbation, burrows, and concretions occurred throughout this sediment. At a depth of $6.24-10.49 \mathrm{~m}$, the subtidal species of mollusks such as $P$. undulatus and Dosinella angulosa (Philippi 1847) were recognized. At a depth of 2.27-5.45 m, the subtidal to intertidal species such as Ruditapes philippinarum (Adams and Reeve 1850) and Anomalodiscus squamosus (Linnaeus 1758), and intertidal species such as Batillaria multiformis (Lischke 1869) and $P$. pupiformis, were found. In the interval of $12.58-12.60 \mathrm{~m}$ depth, ostracod taxa such as L. uranouchiensis, S. quadriaculeata, and Cytheromorpha acupunctata were found. The ${ }^{14} \mathrm{C}$ ages of seven pairs of plant and shell samples from 2.26$12.24 \mathrm{~m}$ depth were 490-6360 BP (501-7157 cal BP, 2 $\sigma$ ranges).

\section{Interpretation}

The fine mud with few terrestrial plant remains and abundant marine shells also suggests that this sediment was deposited in a deep water environment. The ostracod taxa dwell in sandy or muddy bottom in a bayhead (Ishizaki 1968; Yasuhara and Irizuki 2001). The change in molluscan assemblages from subtidal to intertidal species indicates that the marine environment became shallower, probably as a result of river-mouth progradation. The increase of weight in plant and shell detritus with decreasing depth (Figure 2) also supports an upward shallowing of water depth. Thus, we concluded that this sediment formed in a deltaic inner bay environment.

\section{Tidal Flat Facies (core depths of $1.36-2.16 \mathrm{~m}$ )}

\section{Description}

This facies could be divided into an upper unit consisting of alternating beds of sandy mud and coarse sand, and a lower unit of organic-rich mud bed. Intertidal species of mollusks such as $P$. pupiformis, and brackish to freshwater Clithon retropictum (v. Martens, 1878) were recognized at a depth of $2.09-2.13 \mathrm{~m}$.

\section{Interpretation}

We inferred that this sediment accumulated on a tidal flat because it contains organic-rich mud and intertidal to freshwater shells.

\section{Embankment (core depths of $\mathbf{0 . 0 0 - 1 . 3 6 ~ m ) ~}$}

\section{Description}

This facies consisted of a sandy gravel bed. A piece of pottery and a piece of brick were found in the upper part of this sediment.

\section{Interpretation}

We concluded that this sediment was an embankment formed by humans because of the artificial products in it and the land-use history. 


\section{DISCUSSION}

\section{Accumulation Curves}

On the basis of 23 radiocarbon ages from the SKM core, two accumulation curves were constructed according to the ages of plant remains and shells, which were interpreted using the scatter pattern in an age/depth diagram and using stratigraphic interpretation (Figure 2). The age/depth diagram indicated that four $(4 / 23=15 \%)$ samples should be ignored in the interpretation of the accumulation curves and for MRE. These samples included a pair sampled from a depth of $30.335 \mathrm{~m}$ that was $580-1680 \mathrm{yr}$ younger than pairs from a depth of $22.855-25.73 \mathrm{~m}$ and previous ages. We determined that these samples, KGM-OWd180047 and OCa180023, were dropped from the upper borehole during the drilling process. In contrast, a shell fragment from a depth of $3.57 \mathrm{~m}$ and a piece of wood from a depth of $2.26 \mathrm{~m}$ were $820-1110 \mathrm{yr}$ older than their paired samples and previous ages. We judged that these samples, OCa180014 and OWd180037, were reworked because no problems were found in the sample treatment and measurement procedures. This sediment reworking would result from the low accumulation rate of the environment (ca. $0.08 \mathrm{~cm} / \mathrm{yr}$ ).

\section{Marine Reservoir Effects of the SKM Core and the Trend}

Eight offsets in the ${ }^{14} \mathrm{C}$ ages between pairs of plant remains and shells, induced by the MRE, were interpreted from the same horizons of the SKM core from 4100-9200 cal BP (Figure 2). The reservoir ages $(\mathrm{R})$ from the transgressive inner bay sediment was $310 \pm 70 \mathrm{yr}(\mathrm{n}=3$ : nos. 6-8 in Figure 3). The chronological increasing trend of the MRE from $250 \pm 60$ to $390 \pm 60 \mathrm{yr}$ was identified during 7400-9200 cal BP. Similar trend was also recognized in two cores of Hakata Bay during 7500-9000 cal BP (Nakanishi et al. 2017a) and four cores of the west and south coast of Korea during 3000-4000, 6500-7000, and 7500-8000 cal BP (YAR-4 core; Nakanishi et al. 2013, S13, S15 and W17 cores; Nakanishi et al. 2015a). These changes would be related to the increased marine water influence induced by rising sea levels in this region. On the other hand, the average value from the deltaic inner bay sediment was $340 \pm 80 \mathrm{yr}(\mathrm{n}=5$ : nos. $1-5$ in Figure 3$)$. These $\mathrm{R}$ values are consistent with the one obtained from the transgressive inner bay sediment. The chronological decreasing trend of the MRE from $430 \pm 60$ to $260 \pm 60 \mathrm{yr}$ was identified during $4100-5100 \mathrm{cal} \mathrm{BP}$. This trend was identified from uppermost two pairs (nos. 1-2 in Figure 3) because we could not estimate $\mathrm{R}$ values from upper part of the deltaic facies in low accumulation rate. Similar trend was recognized in YAR-4 core from southwest Korea during 4100-5100 cal BP (Nakanishi et al. 2013). These changes would be also related to the increased freshwater influence induced by a delta progradation.

\section{Correlation with Other East Asian Results}

The calculated $\mathrm{R}$ values of the SKM core ranged from $260 \pm 70$ to $430 \pm 70 \mathrm{yr}$, and the total average and standard deviation value was $330 \pm 70 \mathrm{yr}$. These results were consistent with previously determined values, such as an average of $310 \pm 130 \mathrm{yr}(\mathrm{n}=7)$, ranging from $210 \pm 70$ to $580 \pm 70 \mathrm{yr}$, obtained from the Oita Plain from 6180-10,410 cal BP (KUO1 in Figure 3; Nakanishi et al. 2017c). Moreover, these values were similar to an average of $310 \pm 150 \mathrm{yr}(\mathrm{n}=33)$, ranging from $60 \pm 140$ to $800 \pm 150 \mathrm{yr}$, obtained from Hakata Bay during 2000-9000 cal BP (HKA, HIUBj and HIUBt in Figure 3; Nakanishi et al. 2017a). They were also consistent with previous values from prebomb coral skeletons under the Kuroshio environment: an average of $250 \pm 70 \mathrm{yr}(\mathrm{n}=11)$, ranging from $140 \pm 40$ to 


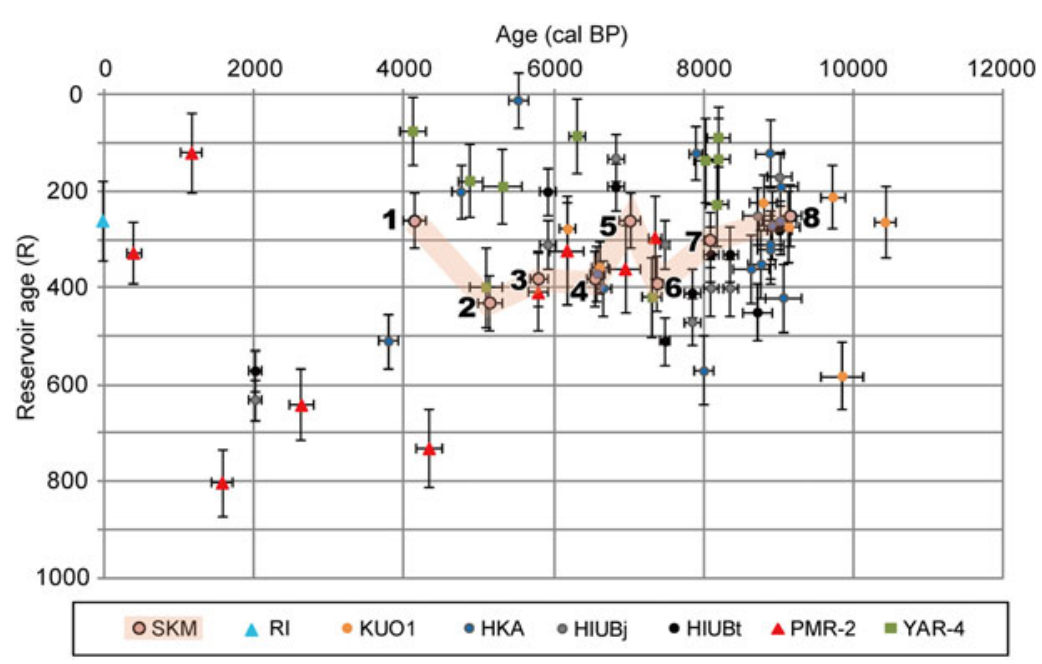

Figure 3 Reservoir ages of the SKM core and from previous studies of southwest Japan and Korea. KUO1 was from the Oita Plain (Nakanishi et al. 2017c). RI was from the Ryukyu Islands (Hirabayashi et al. 2017). HKA, HIUBj and HIUBt were from Hakata Bay (Nakanishi et al. 2017a). PMR-2 was from the eastern coast of Korea (Nakanishi et al. 2017b). YAR-4 was from the southwestern coast of Korea (Nakanishi et al. 2013). Sampling sites of these samples are shown in Figure 1.

$350 \pm 30 \mathrm{yr}$, that was obtained from Kikai Island and Ishigaki Island, from AD 1901-1947 and 1947-1950, respectively (RI in Figure 3; Hirabayashi et al. 2017). However, these values were approximately $100-180 \mathrm{yr}$ less than those reported for the South China Sea and offshore from Taiwan, from 1000-8000 cal BP (Yu et al. 2010; Yang et al. 2018). It might reflect the variations of reservoir age affected by different branches of the Kuroshio Current. Similar differences were recognized when the average reservoir values from southwestern Japan were slightly smaller than the values from the Korean Peninsula, $380 \pm 190 \mathrm{yr}(\mathrm{n}=48)$, from $60 \pm 60$ to $1000 \pm 60 \mathrm{yr}$, as determined from seven sediment cores from the western and southern coast dating to $100-8200$ cal BP (YAR-4 in Figure 3; Nakanishi et al. 2013, 2015); and $450 \pm 230 \mathrm{yr}(\mathrm{n}=9)$, from $120 \pm 80$ to $800 \pm 70 \mathrm{yr}$, as determined from a core from the east coast dating to 300-7300 cal BP (PMR-2 in Figure 3; Nakanishi et al. 2017b). They might reflect the variations of reservoir age between the Kuroshio Current and the Tsushima Current and/or the Liman Current.

\section{CONCLUSIONS}

Seven sedimentary facies were identified (a braided river channel, a meandering river, an estuary, a transgressive inner bay, K-Ah volcanic ash, a deltaic inner bay, and a tidal flat), beneath the artificial soil of the Sukumo Plain, in the southwest coast of Shikoku Island. Reservoir ages were determined from eight marine shell and terrestrial plant pairs in sediments of the transgressive inner bay and deltaic inner bay facies, and the average value during 4100-9200 cal BP was $330 \pm 70{ }^{14} \mathrm{C}$ yr, within $260 \pm 70$ to $430 \pm 70{ }^{14} \mathrm{C}$ yr. This value measured from beneath the Kuroshio Current is similar to those measured from the Hakata Bay, Oita Bay, Ryukyu Islands, and Korean Peninsula; however, it is approximately 100 years younger than the values offshore from Taiwan and the South China Sea. 


\section{ACKNOWLEDGMENTS}

The authors thank Drs. Junghun Park and Gyujun Park for their support in the AMS ${ }^{14} \mathrm{C}$ measurement at KIGAM. This manuscript was improved by constructive comments from two anonymous referees and two editors. The study was partially funded by the Japan Society for the Promotion of Science Kakenhi grant number JP18H01310.

\section{REFERENCES}

Brock F, Higham T, Ditchfield P, Bronk Ramsey C. 2010. Current pretreatment methods for AMS radiocarbon dating at the Oxford Radiocarbon Accelerator Unit (ORAU). Radiocarbon 52(1):103-112.

Fitch TJ, Scholz CH. 1971. Mechanism of underthrusting in southwest Japan: a model of convergent plate interactions. Journal of Geophysical Research 76(29):7260-7292.

Fujiwara O, Machida H, Shiochi J. 2010. Tsunami deposit from the 7300 cal BP Akahoya eruption preserved in the Yokoo midden, north Kyushu, West Japan. The Quaternary Research (Daiyonki Kenkyu) 49(1):23-33. In Japanese with English abstract.

Geshi N, Maeno F, Nakagawa S, Naruo H, Kobayashi T. 2017. Tsunami deposits associated with the $7.3 \mathrm{ka}$ caldera-forming eruption of the Kikai Caldera, insights for tsunami generation during submarine calderaforming eruptions. Journal of Volcanology and Geothermal Research 347:221-233.

Hideshima S, Matsumoto E, Abe O, Kitagawa $\mathrm{H}$. 2001. Northwest Pacific marine reservoir correction estimated from annually banded coral from Ishigaki island, southwest Japan. Radiocarbon 43(2A):473-476.

Hirabayashi S, Yokoyama Y, Suzuki A, Miyairi Y, Aze T. 2017. Short-term fluctuations in regional radiocarbon reservoir age recorded in coral skeletons from the Ryukyu Islands in the northwestern Pacific. Journal of Quaternary Science 32(1):1-6.

Hong W, Park JH, Kim KJ, Woo HJ, Kim JK, Choi HK, Kim GD. 2010a. Establishment of chemical preparation methods and development of an automated reduction system for AMS sample preparation at KIGAM. Radiocarbon 52(3): 1277-1287.

Hong W, Park JH, Sung KS, Woo HJ, Kim JK, Choi HW, Kim GD. 2010b. A new1MV AMS facility at KIGAM. Radiocarbon 52(2):243-251.

Irizuki T, Seto K, Nomura R. 2008. The impact of fish farming and bank construction on Ostracoda in Uranouchi Bay on the Pacific coast of southwest Japan-Faunal changes between 1954 and 2002/2005. Paleontological Research 12(3):282-302.

Ishizaki K. 1968. Ostracodes from Uranouchi Bay, Kochi Prefecture, Japan. Science Reports of the
Tohoku University, Sendai, Second Series (Geology) 40:1-45.

Kong GS, Lee CW. 2005. The Sea, Journal of the Korean Society of Oceanography 10(2):124 128. In Korean with English abstract.

Konishi K, Tanaka T, Sakanoue M. 1982. Secular variation of radiocarbon concentration in seawater: Sclerochronological approach. Proceedings of the 4th International Coral Reef Symposium, Manira. p. 181-185.

Kuzmin YV, Burr GS, Jull AJT. 2001. Radiocarbon reservoir correction ages in the Peter the Great Gulf, Sea of Japan, and eastern coast of the Kunashir, Southern Kuriles (Northwestern Pacific). Radiocarbon 43(2):477-481.

Kuzmin YV, Burr GS, Gorbunov SV, Rakov VA, Razjigaeva NG. 2007. A tale of two seas: Reservoir age correction values $(\mathrm{R}, \Delta \mathrm{R})$ for the Sakhalin Island (Sea of Japan and Okhotsk Sea). Nuclear Instruments and Methods in Physics Research B 259(1):460-462.

Machida H, Arai F. 2003. Atlas of tephra in and around Japan. University of Tokyo Press. 336 p.

Maeno F, Imamura F. 2007. Numerical investigations of tsunamis generated by pyroclastic flows from the Kikai caldera, Japan. Geophysical Research Letters 34: L23303. doi: 10.1029/2007GL031222.

Maeno F, Imamura F, Taniguchi H. 2006. Numerical simulation of tsunamis generated by caldera collapse during the $7.3 \mathrm{ka}$ Kikai eruption, Kyushu, Japan. Earth Planets Space 58:1-12.

Miall AD. 1977. A review of the braided-river depositional environment. Earth Science Reviews 13:1-62.

Miall AD. 1992. Alluvial deposits. In: Walker RG, James NP, editors. Facies models: response to sea level change. Geol. Assoc. Can. p. 119-142.

Nakamura T, Masuda K, Miyake F, Hakozaki M, Kimura K, Nishimoto H, Hitoki E. 2016. Highprecision age determination of Holocene samples by radiocarbon dating with accelerator mass spectrometry at Nagoya University. Quaternary International 397:250-257.

Nakanishi T, Hong W, Sung KS, Lim J. 2013. Radiocarbon reservoir effect from shell and plant pair in Holocene sediments around the Yeongsan River in Korea. Nuclear Instruments and Methods in Physics Research B 294:444-451.

Nakanishi T, Hong W, Sung KS, Sung KH, Nakashima R. 2015. Offsets in radiocarbon 
ages between plants and shells from same horizons of coastal sediments in Korea. Nuclear Instruments and Methods in Physics Research B 361: 670-679.

Nakanishi T, Hong W, Shimoyama S, Sato S, Park G, Lee JG. 2017a. Radiocarbon age offset between shell and plant pairs in the Holocene sediments under the Hakata Bay, western Japan. Radiocarbon 59(2):423-434.

Nakanishi T, Hong W, Sung KS, Nakashima R, Nahm WH, Lim J, Katsuki K. 2017b. Offset in radiocarbon age between plant and shell pairs in Holocene sediment around the Mae-ho Lagoon on the eastern coast of Korea. Quaternary International 447:3-12.

Nakanishi T, Takemura K, Matsuyama H, Shimoyama S, Hong W, Okuno M. 2017c. Activity of the Funai fault and radiocarbon age offsets of shell and plant pairs from the latest Pleistocene to Holocene sediments beneath the Oita Plain, western Japan. Radiocarbon 59(6):1737-1748.

Nanayama F, Maeno F. 2018. Evidence on the Koseda coast of Yakushima Island of a tsunami during the $7.3 \mathrm{ka}$ Kikai caldera eruption. Island Arc 2018: e12291. doi: 10.1111/iar.12291.

Okamura Y. 1990. Geologic structure of the upper continental slope off Shikoku and Quaternary tectonic movement of the outer zone of southwest Japan. Journal of Geological Society of Japan (Chishitsugaku Zasshi) 96(3):223-237. In Japanese with English abstract.

Okutani T. 2017. Marine mollusks in Japan. 2nd ed. Tokai University Press. 1375 p. In Japanese with English abstract.

Park J, Hong W, Woo HJ, Choi HW, Kim J, Kim GD. 2010. Simple pretreatment method development for iron calcium carbonate samples. Radiocarbon 52(2-3):1295-1300.

Smith VC, Staff RA, Blockley SPE, Bronk Ramsey C, Nakagawa T, Mark DF, Takemura K, Danhara T, Suigetsu 2006 Project Members. 2013. Identification and correlation of visible tephras in the Lake Suigetsu SG06 sedimentary archive, Japan: chronostratigraphic markers for synchronizing of east Asian/west Pacific palaeoclimatic records across the last $150 \mathrm{ka}$. Quaternary Science Reviews 67:121-137.

Reimer PJ, Bard E, Bayliss A, Beck JW, Blackwell PG, Bronk Ramsey C, Buck CE, Cheng H, Edwards RL, Friedrich M, Grootes PM,
Guilderson TP, Haflidason H, Hajdas I, Hatté C, Heaton TJ, Hoffmann DL, Hogg AG, Hughen KA, Kaiser KF, Kromer B, Manning SW, Niu M, Reimer RW, Richards DA, Scott EM, Southon JR, Staff RA, Turney CSM, van der Plicht J. 2013. IntCal13 and Marine13 radiocarbon age calibration curves $0-50,000$ years cal BP. Radiocarbon 55(4):1869-1887.

Shishikura M, Echigo T, Kaneda H. 2007. Marine reservoir correction for the Pacific coast of central Japan using ${ }^{14} \mathrm{C}$ ages of marine mollusks uplifted during historical earthquakes. Quaternary Research 67(2):286-291.

Southon J, Kashgarian M, Fontugne M, Metivier B, Yim WWS. 2002. Marine reservoir corrections for the Indian Ocean and southeast Asia. Radiocarbon 44(1):167-180.

Stuiver M, Reimer PJ, Reimer RW. 2018. CALIB 7.1 [WWW program] at http://calib.org [accessed 2018 Feb 24].

Tanaka K. 1980. Geology of the Iyokashima and Sukumo district. Quadrangle Series, scale 1 :50,000, Geological Survey of Japan. 56 p. In Japanese with English abstract.

Tsuji T, Nanayama F, Yamaguchi T, Ikeda M, Nakanishi T, Kondo Y, Maeno F, Hongo C, Kimura K. 2018. Outline of the Sukumo core and event deposit related with Kikai Akahoya volcanic ash, southwest coast of Shikoku, Japan. Abstract of Japan Geoscience Union Meeting, MIS11-P19.

Yasuhara M, Irizuki T. 2001. Recent Ostracoda from the northeastern part of Osaka Bay, southwestern Japan. Jounral of Geosciences, Osaka City University 44(4):57-95.

Yang RJ, Wang SL, Burr GS, Liu JT, Fan D. 2018. Holocene variation of radiocarbon reservoir age offshore western Taiwan, derived from paired charcoals and mollusks. Quaternary International. doi: 10.1016/j.quaint.2018.07.001

Yoneda M, Uno H, Shibata Y, Suzuki R, Kumamoto Y, Yoshida K, Sasaki T, Suzuki A, Kawahata H. 2007. Radiocarbon marine reservoir ages in the western Pacific estimated by pre-bomb molluscan shells. Nuclear Instruments and Methods in Physics Research B 259:432-437.

Yu K, Hua Q, Zhao JX, Hodge E, Fink D, Barbetti M. 2010. Holocene marine ${ }^{14} \mathrm{C}$ reservoir age variability: evidence from ${ }^{230} \mathrm{Th}$-dated corals in the South China Sea. Palaeoceanography 25: PA3205. 